\title{
Purification of Alpha-Toxin from Staphylococcus aureus and Application to Cell Permeabilization
}

\author{
INGE Lind, ${ }^{*}$ Gudrun AHNERT-Hilger, ${ }^{*}$ Georg Fuchs, $†$ AND MANFred GratzL* \\ *Abteilung Anatomie und Zellbiologie and $\dagger$ Abteilung Angewandte Mikrobiologie der Universität Ulm. \\ D-7900 Ulm, Federal Republic of Germany
}

Received December 29, 1986

\begin{abstract}
Crude alpha-toxin was produced by Staphylococcus aureus, strain Wood 46. The amount of exotoxin was monitored during growth and all subsequent purification steps by determination of its hemolytic activity against rabbit erythrocytes. The culture supernatant was treated with ammonium sulfate (75\% saturation). The resulting precipitate was dialyzed and subjected to cation-exchange chromatography. The fractions containing the hemolytic activity were further purified by gel chromatography. The final product was enriched by a factor of 8.5 compared to the crude toxin. In sodium dodecyl sulfate-polyacrylamide gel electrophoresis the purified toxin exhibited one major band. It caused the release of ${ }^{86} \mathrm{Rb}^{+}$and ATP from rat insulinoma (RIN A2) as well as pheochromocytoma cells (PC12) in culture, indicating efficient permeabilization of their plasma membranes for small molecules. @ 1987 Academic Press, Inc.

KEY WORDS: Staphylococcus; alpha-toxin; purification; cell permeabilization.
\end{abstract}

The study of complex intracellular processes in situ, e.g., metabolic pathways, ion homeostasis, or exocytosis is hampered by the inaccessibility of the interiors of intact cells. The plasma membrane represents a permeability barrier that must be circumvented to afford access to the cytoplasm. Of the different techniques used for this purpose, the use of alpha-toxin produced by Staphylococcus aureus as the reagent appears to be ideal, since the alpha-toxin selectively permeabilizes the plasma membrane, leaving the intracellular $\therefore$ ganelles intact (1-4).

Alpha-toxin, in its monomeric form, is a water-soluble protein that hexamerizes in the target membrane, creating a stable transmembrane pore. The size of the pore formed by the alpha-toxin does not allow intracellular proteins to escape from the cells, whereas low-molecular-weight molecules are released and can thus be exchanged in permeabilized cell preparations $(2-7,16,17)$.

Hitherto alpha-toxin has been used as a valuable tool to investigate the properties of the microsomal glucose-6-phosphatase sys- tem in hepatocytes (4) and the effect of cations and nucleotides on contraction of smooth muscle (8) as well as in the analysis of the minimal requirements for secretion by exocytosis in chromaffin cells (1-3).

Here we report on the production of crude alpha-toxin by Staphylococcus aureus strain Wood 46 and its subsequent purification and characterization. The efficiency of the permeabilization of secretory cells by the isolated toxin was determined by measuring ${ }^{86} \mathrm{Rb}^{+}$efflux and ATP release from a rat pheochromocytoma (PC12) as well as a rat insulinoma (RIN A2) cell line.

\section{MATERIALS AND METHODS}

Preparation of crude toxin. Stock preparations of Staphylococcus aureus (strain Wood 46, ATCC 10832, DSM 20491) were kindly supplied by S. Bhakdi (Institute of Medical Microbiology, University of Giessen, FRG). Cultivation was performed aerobically using a $4 \%$ inoculum from an exponentially growing proculture in $100 \mathrm{ml}$ of medium (tryptic 
soya broth, Difco, $30 \mathrm{~g} /$ liter, $\mathrm{pH}$ 7.2) in 0.5 liter indented Erlenmeyer flasks on a rotary shaker $(120 \mathrm{rpm})$ at $37^{\circ} \mathrm{C}$. At the times indicated growth was determined by measuring the absorbance of an appropriately diluted sample at $578 \mathrm{~nm}$ against the growth medium as a blank. The alpha-toxin content was assayed in the supernatant following centrifugation using the hemolytic titer (see below). After $18 \mathrm{~h}$ the bacteria were harvested by centrifugation at $4^{\circ} \mathrm{C}(20 \mathrm{~min}$ at $16,000 \mathrm{~g}$ ). Solid ammonium sulfate was added (75\% saturation) to the supernatant, which was kept for $2 \mathrm{~h}$ in a cold room. The precipitate formed was collected by centrifugation at $4^{\circ} \mathrm{C}(15 \mathrm{~min}$ at $16,000 \mathrm{~g})$ and stored frozen as a stock of crude toxin.

Purification of alpha-toxin. For purification of alpha-toxin the thawed precipitate was dialyzed overnight against $10 \mathrm{~mm}$ sodium acetate buffer, $\mathrm{pH} 5$, containing $20 \mathrm{mM}$ $\mathrm{NaCl}$. Under these conditions the toxin becomes soluble. Other contaminating proteins that were still insoluble were removed by centrifugation ( $2 \mathrm{~min}$ at $12,000 \mathrm{~g}$ ). The clear supernatant was prefiltered through a $0.22-\mu \mathrm{m}$ membrane filter (Millipore). Ionexchange chromatography and gel filtration were done using the FPLC ${ }^{l}$ technique (Pharmacia). Samples of about $12 \mathrm{mg}$ of protein were first loaded onto a Mono S cation-exchange column (HR 5/5, Pharmacia) equilibrated with $10 \mathrm{mM}$ sodium acetate, $\mathrm{pH} 5$, containing $20 \mathrm{mM} \mathrm{NaCl}$. Elution was carried out with a linear gradient (buffer A, equilibration buffer; buffer $\mathrm{B}, 10 \mathrm{~mm}$ sodium acetate, pH 5 , containing $200 \mathrm{mM} \mathrm{NaCl}$ ): $0-100 \%$ buffer B in 45 min with a flow rate of $60 \mathrm{ml} / \mathrm{h}$. Protein in the effluent was de-

\footnotetext{
' Abbreviations used: FPLC, fast protein liquid chromatography; SDS, sodium dodecyl sulfate; PAGE, polyacrylamide gel electrophoresis; Pipes, 1,4-piperazinediethanesulfonic acid; EGTA, ethylene glycol bis( $\beta$ aminoethyl ether) $N, N^{\prime}$-tetraacetic acid; NTA, nitrilotriacetic acid; $K G$, medium containing 150 mmol/liter $\mathrm{K}^{+}$glutamate, $10 \mathrm{mmol} /$ iter Pipes, 5 $\mathrm{mmol} /$ liter NTA, $0.5 \mathrm{mmol} / \mathrm{liter}$ EGTA, pH 7.2; LDH, lactic dehydrogenase.
}

tected at $280 \mathrm{~nm}$. The fractions containing the alpha-toxin were collected, concentrated

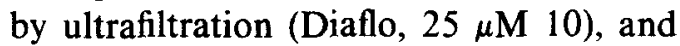
subjected to gel filtration in $200-\mu \mathrm{l}$ samples (each about $3 \mathrm{mg}$ of protein) on a Superose 12-HR 10/30 column (Pharmacia) equilibrated with $10 \mathrm{~mm}$ sodium phosphate, $\mathrm{pH}$ 7.0 , containing $10 \mathrm{mM} \mathrm{NaCl}$. SDS-PAGE and protein determination were done using standard techniques $(9,10)$.

Alpha-toxin determination. Blood was obtained from the rabbit "Aurea" and immediately mixed with $4 \%$ sodium citrate. After three washes with $50 \mathrm{~mm}$ phosphate-buffered saline ( $\mathrm{pH} 7.0$ ), the erythrocytes were diluted to $2.5 \%$ in the same buffer. Fifty microliters of this suspension was mixed with $5 \mu \mathrm{l}$ of appropriate dilutions of the toxin. After incubation for $40 \mathrm{~min}$ at $37^{\circ} \mathrm{C}$ under constant shaking the samples were again mixed followed by centrifugation $(2 \mathrm{~min}$ at $12,000 \mathrm{~g}$ ). Hemoglobin was determined spectrophotometrically at $412 \mathrm{~nm}$ in $30 \mu$ l of the supernatant after addition of $1 \mathrm{ml}$ of distilled water. Total hemolysis was determined after addition of SDS $(0.2 \%, \mathrm{w} / \mathrm{v}$, final). The dilution of toxin hemolyzing $50 \%$ of the red cells was determined and the reciprocal of the value obtained was taken as the number of hemolytic units $(U)$ per milliliter of the undiluted toxin solution (11).

${ }^{86} \mathrm{R} b^{+}$and $A T P$ efflux from secretory cells. Rat pheochromocytoma cells (PC12) were grown as outlined previously (2) and insulinoma cells (RIN A2, kindly supplied by H. P. T. Ammon, Department of Pharmacology, Institute of Pharmaceutical Sciences, University of Tübingen, FRG) were cultured in RPMI medium containing $10 \%$ fetal calf serum. The permeability of the cells was assessed by measuring the release of ${ }^{86} \mathrm{Rb}^{+}(2)$ or of ATP (firefly assay, Boehringer Mannheim, FRG). PC12 cells on plates were washed twice in a medium containing (mmol/liter) $\mathrm{NaCl}(150)$, Pipes (10), EGTA (1), $\mathrm{pH} 7.2$, and once with $\mathrm{KG}$ medium containing $\mathrm{K}^{+}$glutamate (150), Pipes (10), NTA (5), EGTA (0.5), $\mathrm{pH} 7.2$, before suspending 
them in the same buffer supplemented with $0.1 \%$ BSA. After preincubation $(10 \mathrm{~min}$ at $37^{\circ} \mathrm{C}$ ) the cells were permeabilized for 20 min at $37^{\circ} \mathrm{C}$ with either alpha-toxin or digitonin in $\mathrm{KG}$ medium. Then the cells were centrifuged $(0.5 \mathrm{~min}$ at $12,000 \mathrm{~g})$. After the supernatant was removed, the cells were incubated for a further $10 \mathrm{~min}$ at $37^{\circ} \mathrm{C}$ in $\mathrm{KG}$ medium. In order to measure the ATP remaining in the cells, they were extracted with $250 \mu 1$ Tris/acetate buffer (Tris, $50 \mathrm{mmol} /$ liter, pH 7.8; Mg-acetate, $10 \mathrm{mmol} / \mathrm{liter}$; EGTA, $1.5 \mathrm{mmol} / \mathrm{liter}$ ) and immediately heated to $95^{\circ} \mathrm{C}$ for $5 \mathrm{~min}$. ATP was measured in all supernatants and also in the final cell extract. Untreated cells at the beginning of the experiment contained $45 \mathrm{nmol}$ of ATP $/ \mathrm{mg}$ of protein $(100 \%)$, which is in the range of values reported (12).

\section{RESULTS AND DISCUSSION}

Staphylococcus aureus strain Wood 46 exhibited exponential growth in the first $6 \mathrm{~h}$ when grown aerobically on tryptic soy broth (Fig. 1). Toxin production also started during this period, and even when the bacteria reached the stationary phase toxin release into the growth medium continued. The

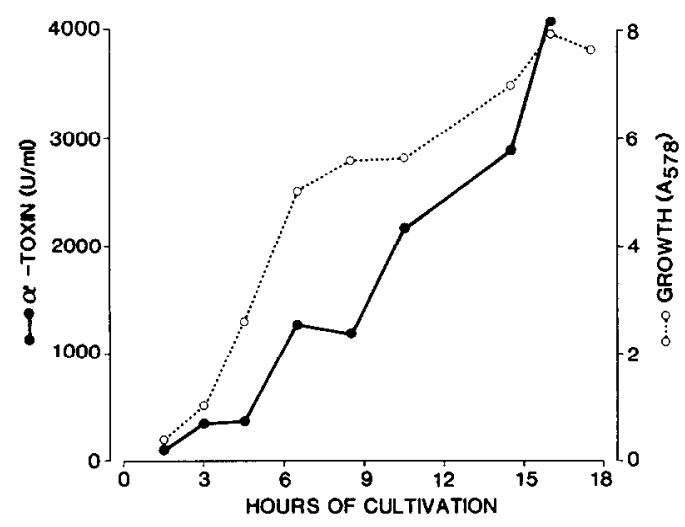

FIG. 1. Growth and production of alpha-toxin by Staphylococcus aureus (Wood 46). Hemolytic units (U) of alpha-toxin per milliliter of supernatant (left) were determined using rabbit erythrocyte suspensions, and growth was monitored by mcasuring the absorbance at $578 \mathrm{~nm}$ (see Materials and Methods).

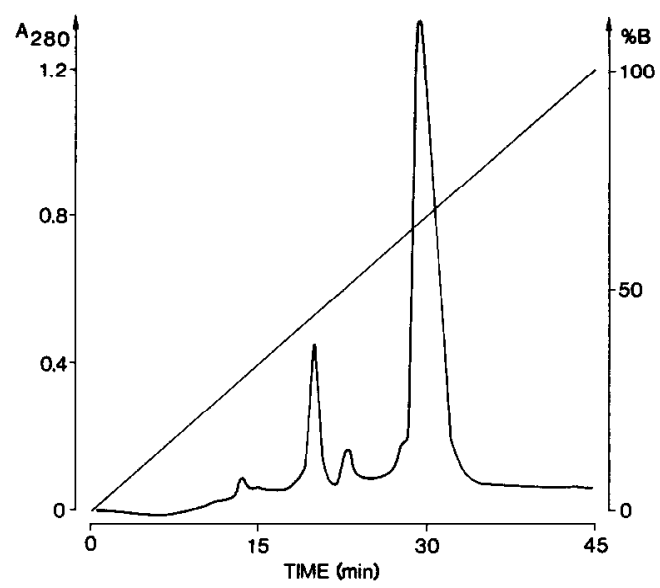

FIG. 2. Cation-exchange chromatography of crude alpha-toxin. Separation of alpha-toxin was achieved on a Mono-S column using a sodium chloride gradient. Eluants: A, $10 \mathrm{~mm}$ sodium acetate, $\mathrm{pH}$, containing 20 $\mathrm{mM} \mathrm{NaCl} ; \mathrm{B}, 10 \mathrm{mM}$ sodium acetate, $\mathrm{pH}$ 5, containing $200 \mathrm{mM} \mathrm{NaCl}$. Hemolytic activity was found exclusively in the main protein peak appearing after $30 \mathrm{~min}$. Detection of protein was carried out at $280 \mathrm{nM}$.

crude toxin harvested after $18 \mathrm{~h}$ and precipitated with ammonium sulfate (see Materials and Methods) contained $3600 \pm 1000$ units/ $\mathrm{mg}$ of protein $(n=6)$. After dialysis and removal of insoluble proteins by centrifugation the toxin was subjected to cation-exchange chromatography on a Mono-S column. The alpha-toxin-containing fractions (see main peak in Fig. 2) were eluted after $30 \mathrm{~min}$ with $170 \mathrm{mM} \mathrm{NaCl}$ present in the column buffer (10 mm sodium acetate, $\mathrm{pH}$ 5). Cation-exchange chromatography resulted in a 6.5 fold enrichment of the toxin. The enrichment of the toxin and removal of most protein bands was also shown by SDS-PAGE (Fig. 3). However, at this stage contaminating proteins of molecular weights lower than that of the alpha-toxin monomer ( $34 \mathrm{kDa})$ were present. These proteins were successively removed by gel chromatography (see Materials and Method and Fig. 4) which yielded the final product. Also, SDS-PAGE indicated a further purification (Fig. 3) after this step. The alpha-toxin isolated by the procedures described above contained 


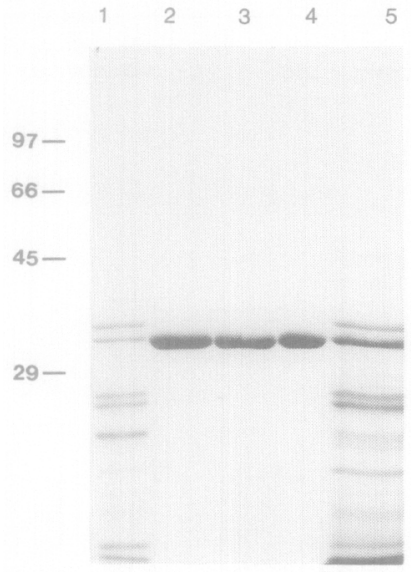

FIG. 3. Analysis of the alpha-toxin fractions by SDSPAGE. The samples (lanes 1-4, $1.5 \mu \mathrm{g}$; lane 5. $15 \mu \mathrm{g}$ protein) were separated in $12 \%$ acrylamide gels. The indicated molecular weight values $(\mathrm{kDa})$ were determined by running standards in parallel (carbonic anhydrase 29; ovalbumin 45 ; albumin 66 ; phosphorylase $b 97$ ). The gel was stained in Coomassie blue. The ammonium sulfate precipitate of the culture supernatant prior to (sample 5) and after (sample 1) dialysis plus removal of insoluble proteins by centrifugation differ greatly from the alphatoxin fractions eluted during cation-exchange chromatography (samples 2 and 3). Following gel chromatography (sample 4) only one protein band is observed.

$31,100 \pm 4500$ units/mg of protein $(n=6)$, i.e., the purification achieved was 8.5 times that of the crude toxin.

The specific activity of the purified alphatoxin compared well with other preparations carried out with less advanced protein purification methods (cf. (13)). One advantage of the procedure described here is that, starting with the dialyzed ammonium sulfate precipitate of the culture supernatant, purified alpha-toxin can be obtained within $2 \mathrm{~h}$. The purified toxin was stable for several weeks at $4^{\circ} \mathrm{C}$ after the addition of ammonium sulfate ( $75 \%$ saturation). When the toxin was rapidly frozen in liquid nitrogen and kept at $-20^{\circ} \mathrm{C}$ no loss of toxicity was observed for several months.

Alpha-toxin causes hemolysis of erythrocytes of various species. The channels formed do not allow the passage of myoglobin $(17 \mathrm{kDa})$ or Dextran $4(4 \mathrm{kDa})(5,6)$.
Thus it is highly unlikely that the native alpha-toxin molecules ( $34 \mathrm{kDa}$ ) are able to cross such channels and gain access to the intracellular space. This is an important feature for its application to selective permeabilization of the plasma membranes of secretory cells in order to study the requirements for exocytosis under controlled conditions with respect to ions, nucleotides, and other small molecules.

Alpha-toxin elicits the release of ${ }^{86} \mathrm{Rb}^{+}$, reflecting the effective permeabilization to ions when applied to pheochromocytoma cells (2), chromaffin cells in primary culture (3), and insulinoma cells (Fig. 5) in a dose-dependent manner. In this respect it resembles digitonin, which has been used by several groups for the permeabilization of chromaffin cells (cf. $(3,14,15)$ ). In contrast with digitonin, alpha-toxin does not cause the escape of $\mathrm{LDH}(150 \mathrm{kDa})$ from either pheochromocytoma cells or chromaffin cells in primary culture $(2,3)$, a fact which is in accordance

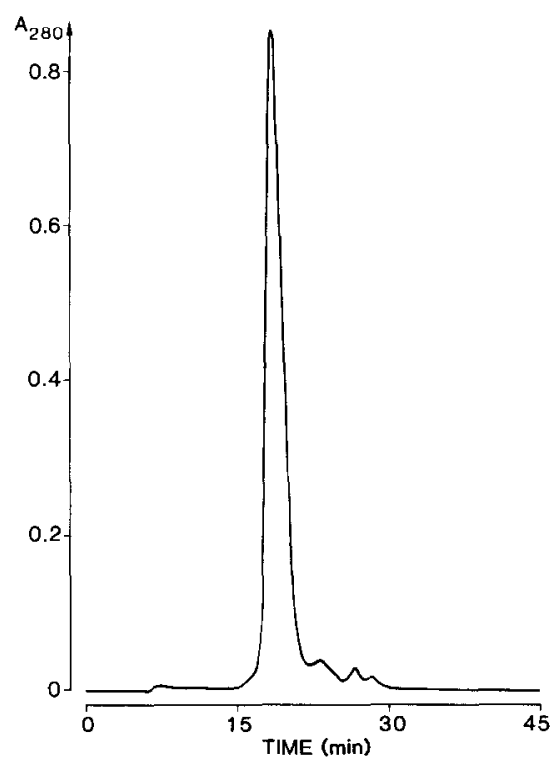

FIG. 4. Gel filtration of the alpha-toxin fraction eluted from the cation exchanger. Protein ( $3 \mathrm{mg}$ ) of the toxincontaining fractions recovered from the cation-exchange column (see Fig. 3) was separated on a Superose 12-HR $10 / 30$ column. Alpha-toxin was present in only the main peak (detection of protein was carried out at $280 \mathrm{~nm}$ ). 
with findings observed with erythrocytes (see above).

The investigation of the intracellular requirements for exocytosis by secretory cells is the main interest of the authors' laboratory. $\mathrm{Ca}^{2+}$ - and $\mathrm{Mg}^{2+}-\mathrm{ATP}$ are important factors for the final step in exocytosis in permeabilized chromaffin cells in primary culture (3). On the other hand, the rat pheochromocytoma cells, when permeabilized by alphatoxin, do not depend on added $\mathrm{Mg}^{2+}$-ATP $(1,2)$. The reason for this observation certainly is not the ineffectiveness of the perturbant. Here we clearly demonstrate that the holes generated by alpha-toxin are sufficient to deplete PC12 cells of their cytoplasmic ATP at a level comparable in magnitude to digitonin (Fig. 6). Release of small molecules of similar size (e.g., $\alpha$-amino acids) by alpha-toxin has been also observed in fibroblasts (7).

The effects of detergents like digitonin and saponin are difficult to control due to their

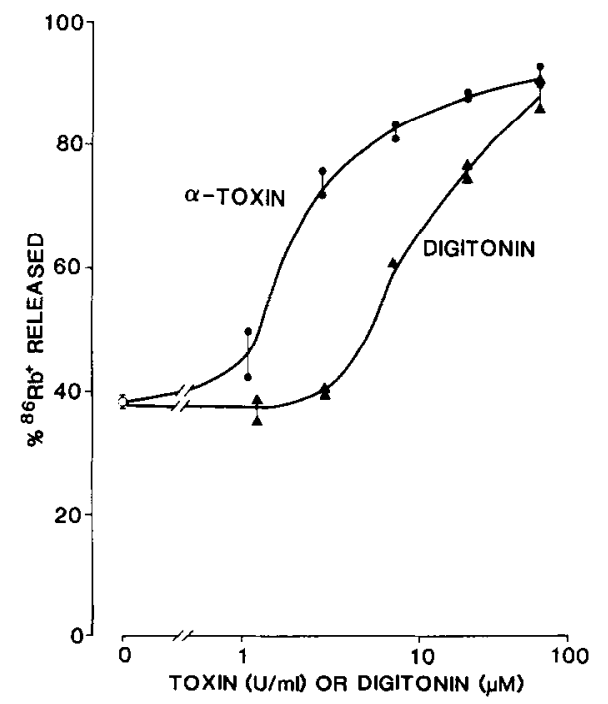

FIG. $5 .{ }^{86} \mathrm{Rb}^{+}$release from alpha-toxin- and digitoninpermeabilized rat insulinoma cells. The cells were treated with alpha-toxin or digitonin and the percentage of ${ }^{86} \mathrm{Rb}^{+}$released was determined after $20 \mathrm{~min}$. Both substances caused a dose-dependent release of ${ }^{86} \mathbf{R b}^{+}$ from the cells. The abscissa gives the final concentration of toxin in hemolytic units per milliliter or of digitonin in micromoles per liter.

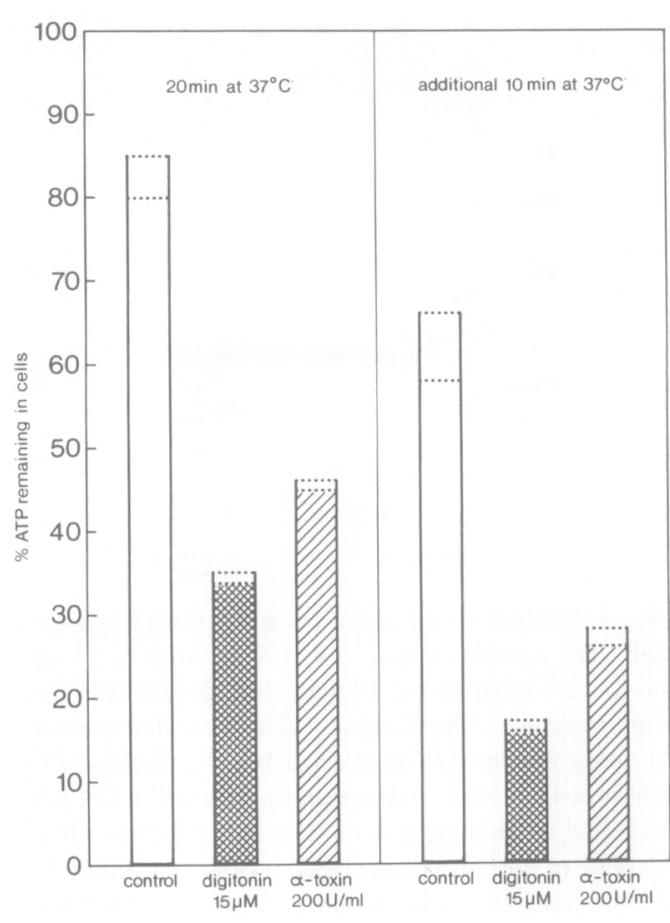

FIG. 6. Release of ATP from rat pheochromocytoma cells treated with alpha-toxin or digitonin. $\mathrm{PC} 12$ cells grown as described (2) contain $45 \mathrm{nmol}$ of ATP/mg of protein $(100 \%)$. When incubated for $20 \mathrm{~min}$ at $37^{\circ} \mathrm{C}$ with alpha-toxin or digitonin they release ATP. An additional incubation for $10 \mathrm{~min}$ resulted in a further reduction of cell-associated ATP (see also Materials and Methods). The dotted lines represent single values.

lack of specificity and the detergents have the disadvantage of lysing all cellular membranes, thereby disintegrating the whole cell. The attack by alpha-toxin, however, is restricted to the plasma membrane and even at very high concentrations it leaves the secretory vesicles intact, as seen by the retention of catecholamines and of chromogranin A within the cells $(2,3)$.

Thus, alpha-toxin allows the control of intracellular cations and anions without impairing the exocytotic machinery (1-3). This opens up the possibility of directly studying fusion of secretory vesicles and the plasma membrane in situ. Permeabilization with alpha-toxin can also be used to follow muscle contraction (7) and complex enzymatic reac- 
tions (4) within different cells, i.e., processes which require a precise structural array of components for their proper function.

\section{ACKNOWLEDGMENTS}

The authors thank Mrs. M. Rudolf and Y. Czeruy for technical assistance and Mrs. B. Mader for preparation of this manuscript. This work was supported by the Deutsche Forschungsgemeinschaft (Gr 681) and by Forschungsschwerpunkt No. 24 of the State of BadenWürttemberg.

\section{REFERENCES}

1. Ahnert-Hilger, G., Bhakdi, S., and Gratzl, M. (1985) Neurosci. Lett. 58, 107-110.

2. Ahnert-Hilger, G., Bhakdi, S., and Gratzl, M. (1985) J. Biol. Chem. 260, 12730-12734.

3. Bader, M. F., Thierse, D., Aunis, D., Ahnert-Hilger, G., and Gratzl, M. (1986) J. Biol. Chem. 261, 5777-5783.

4. McEwen, B. F., and Arion, W. J. (1985) J. Cell Biol. 100, 1922-1929.

5. Füssle, R., Bhakdi, S., Sziegoleit, A.. Tranum-Jensen, J., Kranz, T., and Wellensiek, H. J. (1981) J. Cell Biol. 91, 83-94.
6. Bhakdi, S., Füssle, R., and Tranum-Jensen, J. (1981) Proc. Natl. Acad Sci. USA 78, 5475-5479.

7. Thelestam, M., and Möllby, R. (1979) Biochim. Biophys. Acta 557, 156-169.

8. Cassidy, P., Hoar, P. E., and Kerrick, W. G. L. (1978) Biophys. J. 21, 44.

9. Laemmli, U. K. (1970) Nature (London) 227 , 680-685.

10. Lowry, O. H., Rosebrough, N. J., Farr, A., and Randall, R. J. (1951) J. Biol. Chem. 193, 265-275.

11. Wadström, T. (1968) Biochim. Biophys. Acta 168, 228-242.

12. Reynolds, E. E., Melega, W. P., and Harrod, B. D. (1982) Biochemistry 21, 4795-4799.

13. Möllby, R. (1983) in Staphylococci and Staphylococcal Infections (Easmon, C. S., and Adlam, C., Eds.), Vol. 2, pp. 619-669, Academic Press, London/New York.

14. Dunn, L. A., and Holz, R. W. (1983) J. Biol. Chem. 258, 4989-4993.

15. Wilson, S. P., and Kirshner, N. (1983) J. Biol. Chem. 258, 4994-5000.

16. Bhakdi, S., Muhly, M., and Füssle, R. (1984) Infect. Immun. 46, 318-323.

17. Bhakdi, S., and Tranum-Jensen, J. (1987) Rev. Physiol. Biochem. Pharmacol. 107, 147-223. 